\title{
HIV among out-of-school youth in Eastern and Southern Africa: a review
}

\author{
Koen Stroeken \\ Ghent University \\ Pieter Remes \\ Medical Research Council, Glasgow, UK \\ Petra De Koker \\ Ghent University \\ Kristien Michielsen \\ Ghent University \\ Anke Van Vossole \\ Ghent University
}

See next page for additional authors

Follow this and additional works at: https://ecommons.aku.edu/eastafrica_fhs_mc_obstet_gynaecol

Part of the Obstetrics and Gynecology Commons

\section{Recommended Citation}

Stroeken, K., Remes, P., De Koker, P., Michielsen, K., Vossole, A. V., Temmerman, M. (2012). HIV among out-of-school youth in Eastern and Southern Africa: a review. AIDS Care, 24(2), 186-194.

Available at: https://ecommons.aku.edu/eastafrica_fhs_mc_obstet_gynaecol/74 


\section{Authors}

Koen Stroeken, Pieter Remes, Petra De Koker, Kristien Michielsen, Anke Van Vossole, and Marleen Temmerman 


\section{HAL \\ Hat}

\section{HIV among out-of-school youth in Eastern and Southern Africa: a review}

Koen Stroeken, Pieter Remes, Petra De Koker, Kristien Michielsen, Anke Van Vossole

\section{To cite this version:}

Koen Stroeken, Pieter Remes, Petra De Koker, Kristien Michielsen, Anke Van Vossole. HIV among out-of-school youth in Eastern and Southern Africa: a review. AIDS Care, Taylor \& Francis (Routledge), 2011, pp.1. .

\section{HAL Id: hal-00720582 https://hal.archives-ouvertes.fr/hal-00720582}

Submitted on 25 Jul 2012

HAL is a multi-disciplinary open access archive for the deposit and dissemination of scientific research documents, whether they are published or not. The documents may come from teaching and research institutions in France or abroad, or from public or private research centers.
L'archive ouverte pluridisciplinaire HAL, est destinée au dépôt et à la diffusion de documents scientifiques de niveau recherche, publiés ou non, émanant des établissements d'enseignement et de recherche français ou étrangers, des laboratoires publics ou privés. 

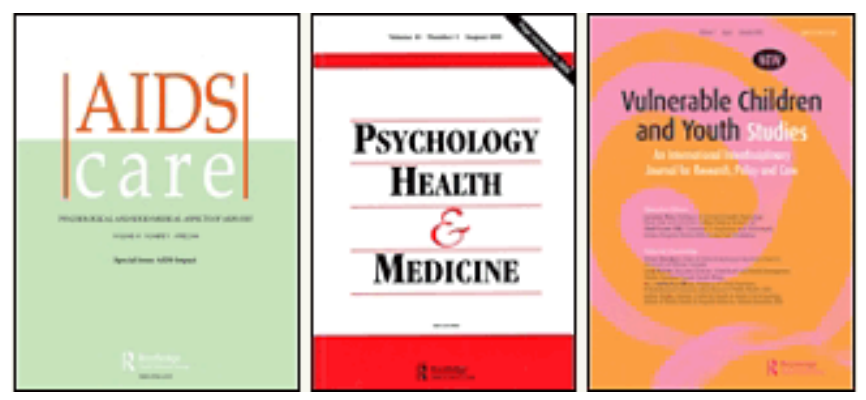

\section{HIV among out-of-school youth in Eastern and Southern Africa: a review}

\begin{tabular}{|r|l|}
\hline Journal: & $\begin{array}{l}\text { AIDS Care - Psychology, Health \& Medicine - Vulnerable Children } \\
\text { and Youth Studies }\end{array}$ \\
\hline Manuscript ID: & AC-2011-02-0082.R2 \\
\hline Journal Selection: & AIDS Care \\
\hline Keywords: & $\begin{array}{l}\text { Review, HIV/ AIDS, Out-of-school youth, Sub-Saharan Africa, Risky } \\
\text { sexual behavior }\end{array}$ \\
\hline \multicolumn{2}{|r}{} \\
\hline
\end{tabular}

\section{SCHOLARONE ${ }^{\text {m }}$ Manuscripts}




\section{HIV among Out-of-School Youth in Eastern and Southern Africa: a review}

\section{ABSTRACT}

The overall decline of the HIV epidemic in Sub-Saharan Africa conceals how the HIV burden has shifted to fall on areas that have been more difficult to reach. This review considers out-of-school youth, a category typically eluding interventions that are school-based. Our review of descriptive studies concentrates on the most affected region, Southern and Eastern Africa, and spans the period between 2000 and 2010. Among the relatively small but increasing number of studies, out-of-school youth was significantly associated with risky sexual behavior (RSB), more precisely with early sexual debut, high levels of partner concurrency, transactional sex, age-mixing, low STI/HIV risk perception, a high lifetime number of partners, and inconsistent condom use. Being-in-school not only raises health literacy. The in-school (e.g., age-near) sexual network may also be protective, an effect which the better-studied (and regionally less significant) variable of educational attainment cannot measure. To verify such double effect of being-in-school we need to complement the behavioral research of the past decade with longitudinal cohort analyses that map sexual networks, in various regions. 


\section{Background}

Out-of-school adolescents are an upcoming population of research in the field of sexual and reproductive health (SRH). Most studies and interventions have targeted in-school youth: they are easier to reach, making surveys and interventions cheaper and less complex in terms of logistics. Given the established role of behavioral change and education in countering the HIV epidemic in SubSaharan Africa (Gillespie et al. 2007), disregarding the out-of-school category is no longer an option.

(INSERT figure 1)

Sub-Saharan Africa has the highest proportion of children out of school with $26 \%$ of the primary school-age population; girls are more often out of school than boys (UNESCO 2009). There are positive trends though. Eastern Africa is catching up with southern Africa, after national policies dropped user-fees at the turn of the century (figures 1 and 2). Since about 1996 Sub-Saharan Africa has witnessed a reversal of association between educational attainment and risk of HIV infection, from hazardous to protective (Michelo et al. 2006, Hargreaves et al. 2008a). Out-of-school youth are the main category failing to benefit from this reversal. Therefore, a systematic review of research relating out-of-school youth and HIV seems timely. Our review covers the last ten years and concentrates on the region most affected by HIV: East and Southern Africa.

(INSERT figure 2)

The association between educational attainment and less RSB is significant, although not uniform across the region. In two thirds of 18 sub-Saharan African countries education is associated with more condom use at last intercourse (Bankole et al. 2009). Education increases health literacy (Bogale et al. 2010) and can delay sexual debut (Gupta and Mahy 2003), which is important because of the role in Southern Africa's generalized HIV epidemic of early sexual debut combined with high levels of partner concurrency (Dixon-Mueller 2009, Kenyon et al. 2009). Partners of 3 years older or more significantly increase the risk of HIV infection (Katz and Low-Beer 2008, Chapman et al. 2010). One factor is the age-disparity hampering negotiation of condom use (Longfield et al. 2004, Clark et al. 2006) as well as hampering STI/HIV risk perception (Clark 2004, Clark et al. 2010).

Hence, termination of a girl's school career due to early marriage deprives her not only of health literacy but also of the school's safer, age-near sex network. The well-studied variable of educational attainment cannot register this second protective effect. A variable determining whether one is in or out of school can.

II. Methods 
The methodology of this review is based upon the PRISMA statement (Moher et al. 2009). Study eligibility and extraction procedures were specified in a systematic review protocol applying the following criteria of inclusion:

- Location: the article must report on Eastern and Southern African countries. Countries included are: Eritrea, Ethiopia, Uganda, Kenya, the United Republic of Tanzania, Burundi, Rwanda, Democratic Republic of the Congo, Malawi, Zambia, Mozambique, Angola, Botswana, Lesotho, Namibia, Swaziland, South Africa, Zimbabwe, Comoro, Madagascar, Seychelles, Mauritius;

- Target population: the article must report on young people aged 10 to 24 years and include out-ofschool youth. We specified additional categories related to out-of-school youth. Firstly, mainstream groups such as pregnant girls and married adolescents, rural boys and girls. Secondly socially marginalized youth, such as street children, orphans and vulnerable children in communities highly affected by HIV, adolescents involved in commercial sex work, child soldiers, migrants, refugee children, drug users and gang members;

- Type of study: the article should report on the status of HIV/STI among youth or on HIV prevention or SRH promotion programs;

- $\quad$ Time limitation: articles should be published between January 2000 and August 2010.

With the corresponding word string, articles were searched in online databases PubMed, ISI Web of Science and OVIDsp. Bibliographic sections of the selected articles were searched as well as 'grey literature' on websites of major international health organizations. To remedy any gaps, four authors of key articles were contacted to suggest additional material. Three authors responded, of whom one suggested two additional papers.

An electronic data extraction sheet was piloted by two authors and refined thereafter. Data extraction was done independently by the five authors. Of the 2216 articles, including 614 duplicates, inclusion criteria were met by 283 descriptive articles and 157 intervention studies. This review considers only the descriptive articles. After assessing the full text, we remained with 19 descriptive studies dealing explicitly with HIV among out-of-school youth in Eastern and Southern Africa (11 from PubMed and 6 from ISI Web of Science). After deducting publications concerning the same study we were left with 16 studies forming the key literature for our review. Twelve are cross-sectional studies of random population samples. Four are qualitative studies, based either on focus group discussions or on in-depth interviews.

(INSERT figure 3) 
III. Results

Since 2007 an increase of publications can be noted on HIV among Eastern and Southern African outof-school youth. The previous ten years were meager. Ethiopia, South Africa, the United Republic of Tanzania and Uganda have benefited more than once from such research; Kenya and Zambia only once. The category has not been put on the research agenda elsewhere. The next two tables schematize the various studies included in this review. Study design and results are specified. Qualitative studies are in table $2(Q=$ qualitative, $I D I=$ in-depth interviews, $F G D=$ Focus Group Discussions). When articles report on the same study, the table of results only includes the earliest publication (the dates of the later publications are between brackets).

(INSERT table 1)

(INSERT table 2)

The first thing that strikes is the lack of standardization in defining youth. Four out of 16 studies opted for teenagers: the age group 10 to 19 years, or 10 to 18 years. This seems advisable so as not to exclude any sexually active youth. Most (6 out of 16) however opted for the groups 13 to 18 years, 13 to 19 years or 12 to 21 years. The rest chose an even older age group: 14 to 21 years, 14 to 25 years, or 15 to 24 years. We may be witnessing a gradual consensus in the field though, because the prevailing trend, since the Zambian study in 2005, is towards the age group of 10 to 19 years, which includes teenagers and excludes older adolescents who are commonly out-of-school anyway.

A second remarkable fact is the dearth of data on HIV serostatus and/or STI infection among out-ofschool youth. Only two studies report on it. In a 2001 sample of 1003 female and 916 male youths in the South African rural province of Limpopo, Hargreaves et al. (2008b) found that the chance of being HIV positive was about $20 \%$ higher for non-students (more exactly, between 0.06 and 0.71 times higher, confidence interval [CI] of 95\%). After adjusting for age the association was no longer significant for women. A urine PCR of 522 adolescents from Addis Ababa showed that Chlamydia trachomatis and Neisseria gonorrhoeae were significantly $(\mathrm{p}<0.05)$ more common among out-ofschool than in-school youth (Taffa et al. 2002a).

The dominant theme of research is risky sexual behavior ( 8 studies) and its counterpart, condom use (7 studies), which usually feature together. HIV/AIDS research traditionally identifies the following eight practices as indicators of risk of infection. In most studies risky sexual behavior is determined by probing a number of these practices.

First, Ndyanabangi et al. (2004) have established in a cross-sectional study in Uganda $(n=556)$ that sexual debut is earlier among out-of-school than in-school youth. The former are also more likely to 
report sexual activity in the past year ( $\mathrm{p}$ 0.001). Taffa et al. (2003) confirm that sexual activity of out-of-school girls in Addis Ababa is higher in comparison to in-school urban girls (between 1.8 and 4.5, $\mathrm{Cl} 95 \%)$. In rural South Africa this is true for out-of-school boys (Hargreaves et al. 2008b).

Secondly, more concurrent or multiple partners are found in the out-of-school category in rural South Africa, for both sexes aged between 14 and 25 (Hargreaves et al. 2008b). A smaller sample of 561 respondents in urban Ethiopia (Addis Ababa) yielded this significant association for young women only (Taffa et al. 2003).

These associations contrast with a recent, more comprehensive cross-sectional study by Masatu et al. (2009) among 3495 boys and girls aged between 10 and 19, of whom 1000 were out-of-school. The data showed less concurrency or multiple partners for out-of-school boys in Tanzania (OR=3.0; $95 \% \mathrm{Cl}=2.2-4.1)$. Unprotected sex and multiple partners were more likely with a factor 2.3 among Christians than among non-Christians. The authors however note that the three villages of the sample were selected for high HIV prevalence and that the local schools may have sexually risky peerpressure cultures.

Third, transactional sex can be a way to gain material support, affirm self-worth, achieve social goals, or increase longer-term life chances. Focus group discussions in Uganda revealed that rural out-ofschool young women find material need a more appropriate motive for sex than pleasure (Nobelius et al. 2010b). In quantitative research among 628 out-of-school youth aged between 15 and 24 in Bahir town, Alemu et al. (2007) observed that the probability of having sex with either a commercial or a non-regular sexual partner rose with a factor ranging between 1.83 and 4.23 (CI 95\%) for out-ofschool adolescents who drink alcohol at least once a week (in comparison to out-of-school youth reporting no alcohol intake). The probability of such sex was also 6 times higher for those chewing khat. The sample did not contain in-school youth for comparison though.

Fourth, in the same study age-mixing often went hand in hand with transactional sex. Junior wives in polygamous marriages engage in cross-generational sex with all the risks attached and suffer from reduced negotiation power. Besides having more concurrent or multiple partners, out-of-school girls in rural South Africa engage more in age-mixing than those in school (Hargreaves et al. 2008b; for partners of three years older: $95 \%$ CI 0.37 to 0.92 ).

Fifth, a large survey comparing in-school and out-of-school youth in South Africa has established that secondary school attendance decreases the lifetime number of partners (Zambuko and Mturi 2005). Female students are less likely to have partners more than three years older than themselves, to have had sex more than five times with a partner and to have had unprotected intercourse during the past year.

Sixth, in the same survey inconsistent condom use was mostly found in South Africa among out-ofschool girls, and more so among those who were never pregnant, hence had less chance of previous 
contact with reproductive health services and their information. Unmarried out-of-school young men tended towards unprotected sex in case they had never impregnated a woman nor engaged in transactional sex. An exacerbating factor was having peers who are indifferent or negative towards condom use.

Our review's cross-sectional studies reveal that out-of-school youth resort less to condoms during casual sex. The seminal study in Zambia by Slonim-Nevo and Mukuka (2005) of randomly selected subsamples containing both rural and urban, out-of-school and in-school, male and female youth aged 10 to $19(n=3360)$ pointed to a higher likelihood $(p<0.01)$ among the out-of-school categories to have unprotected vaginal and anal sex, as well as to be sexually active, combine alcohol and sex, trade sex for money or food, and to have had an STI. Higher risk tendencies were encountered among older and married, poorer and rural out-of-school adolescents. Significantly less condom use among out-of-school youth has been confirmed for Uganda ( $\mathrm{p}$ 0.001; Ndyanabangi et al. 2004). Little over a third of out-of-school young Ethiopians who had sex in exchange for money consistently used a condom (Alemu et al. 2007).

Condom use requires, among others, a certain degree of HIV/AIDS information, more generally termed health literacy, which can be obtained in school. Self-efficacy in SRH planning is an educational outcome often lacking among low-literate rural young women in Ethiopia (Taffa et al. 2002b, 2003). HIV knowledge is relatively low among out-of-school youth, both in Tanzania (Bastien 2008) and in Uganda (Ndyanabangi et al. 2004). In a sample of 1007 urban and rural out-of-school youth (aged 13-18) Bastien (2008) found that boys in urban areas and with higher education are more knowledgeable about HIV/AIDS than their rural, less educated counterparts. The sample did not contain in-school youth to extend the comparison. Bastien's (2009) qualitative study based on 78 IDI described the limited exposure among out-of-school youth to HIV information and their less frequent communication about the topic with peers. Francis and Rimmensberger (2008) paint a similar picture for out-of-school youth in KwaZulu-Natal, South Africa, where the absence of a structured learning environment such as a school prevents these adolescents from breaking with entrenched notions of gender, sexuality and low self-esteem.

(INSERT table 3)

\section{Discussion}

From the results presented above we can only infer that young people in school exhibit individual behavior that is sexually less risky. The logical recommendation is to have youth stay longer in school, beyond the age of sexual maturation. There are a number of caveats though. First, such 
recommendation denies the out-of-school category adapted SRH interventions. The lure of pastoralist and agricultural lifestyles should not be underestimated, nor their incompatibility with school curricula and attendance. Civic organizations and the parental home can be alternatives for the school's protective role (see Harrison et al. 2008). Local bars and media channels such as radio can be used to reach this population (UNFPA 2011).

Secondly, well-targeted interventions require more differentiated descriptions than the conventional one of UNESCO reports considering children to be out-of-school if they had no exposure to school during the school year in question. Children may be officially enrolled in schools yet not attending due to agricultural work, sickness, teacher absence, deaths in the family, the need to care for someone ill at home, or lack of means to cover school-related expenses (Burke and Beegle 2004). SRH profiles will differ between urban and rural out-of-school youth, between street children (whose out-of-school status is rarely mentioned by studies, see UNFPA 2011) and children orphaned by AIDS (who attend school only slightly less, except in Mozambique and Ethiopia, see UNAIDS 2010). Finally, in lowincome countries out-of-school status can be up to sixty percentage points higher among persons with disabilities (UNESCO 2009: 82). In South Africa at least, disability is associated with almost 50\% more HIV prevalence (Shisana et al. 2009: 36). ${ }^{1}$ We advise that future studies on out-of-school youth differentiate their data according to these categories.

Thirdly, the association of out-of-school youth with HIV is unclear as to the direction of causality. No study as yet could exclude that the association stems from HIV infected youth actually leaving school after feeling stigmatized because of their HIV status and/or their RSB. Research among out-of-school cohorts who began to experience symptoms sufficiently long after their schooling period is necessary. Longitudinal cohort studies could reveal whether schools form relatively isolated communities, where risky sexual behavior is epidemiologically less problematic than in the open, densely connected network outside of school. This effect of the sex network is hard to discern through RSB research with its individual-behavioral slant.

The longitudinal cohort study of Bärnighausen et al. (2007) in rural KwaZulu-Natal has summed up the SRH impact of educational attainment in their by now widely cited conclusion that HIV risk decreases with $7 \%$ for each additional year of educational attainment, holding age and sex constant. Can it be generalized? The Demographic and Health Surveys (DHS) of countries neighboring KwaZulu-Natal all exhibit a steady decrease of HIV prevalence as educational attainment advances from the level of lower (or incomplete) primary school to the level of secondary school or more (see country databases at www.measuredhs.com): for women from 33.8 to 30.5 in Swaziland (2006-07), 28.7 to 23.8 in Lesotho (2009), 22.4 to 15.8 in Zimbabwe (2005-06). However, in other southern African countries HIV

\footnotetext{
${ }^{1}$ The association is admittedly hard to ascertain since symptoms of HIV infection can be subsumed under disability due to its broad definition. Respondents with disabilities also score low on HIV status awareness (Shisana et al. 2009: 4, 51).
} 
prevalence rates rise with education from 15.8 to 17.4 in Zambia (2007), 14.4 to 15.0 in Mozambique (2009), 13.2 to 15.1 in Malawi (2004). Future research could determine whether the hazard of the higher educated follows from finding employment after school that expands the sex network. Out-ofschool status might be a stronger SRH discriminant than educational attainment for revealing the respodent's current network. Hence, longitudinal cohort studies can complement RSB research but their significance should be cross-regionally verified.

A final issue is the unexpected higher RSB in rural Tanzanian schools, which Masatu et al. (2009) attribute to peer-pressure. We would rather point to the out-of-school sex network in rural Tanzania where cultivation is demanding and elicits behavioral restraint rather than opportunity for partnering, yet where any globalizing process (e.g., through infrastructure or mining) opening the farmer's protective network can exact a high price for health illiteracy. The widely advertised decline of HIV prevalence rates in Southern and Eastern Africa threatens to obscure where the decline takes place: in the educated urban areas reached by interventions. Prevalence trends among antenatal care attendees reveal a slight to significant rise currently in the rural areas, among others in Malawi, Swaziland, Uganda, Burundi, and Angola (UNAIDS 2010: 17). As the young villagers' sex network opens up we should expect the HIV epidemic to go fully rural, and school to play the protective role.

Conclusion

Out-of-school youth are a particularly vulnerable category, kept under the radar of epidemiological research. Their RSB is more pronounced. Their health literacy is under par. Our review pointed to the importance of (1) scaling up SRH-related research on out-of-school adolescents, including basic biomarker information such as serostatus, (2) standardizing the definition and age-group of this category, (3) acknowledging the proper SRH profile and corresponding needs of out-of-school youth, (4) differentiating between urban and rural risk groups, (5) more longitudinal cohort analyses of the sex networks to end speculations about the causal direction of the established associations, (6) a sustained effort in verifying the cross-regional significance of the associations.

Acknowledgments

Thanks are due to UNFPA for sponsoring the review and to ICRH (UGent) for facilitating it. We are indebted to an anonymous referee for one invaluable reference. 


\section{References}

Alemu, H., Mariam, D.H., Belay, K.A., Davey, G. (2007). Factors predisposing out-of-school youths to HIV/AIDS-related risky sexual behavior in northwest Ethiopia. Journal of Health, Population and Nutrition, 25(3), 344-350.

Bankole, A., Singh, S., Hussain, Oestreicher, R. (2009). Condom use for preventing STI/HIV and unintended pregnancy among young men in Sub-Saharan Africa. American Journal of Men's Health, 3(1), 60-78.

Bärnighausen, T., Hosegood, V., Timaeus, I., Newell. M.-L. (2007). The socioeconomic determinants of HIV incidence: evidence from a longitudinal, population-based study in rural South Africa. AIDS 21: S29-S38

Bastien, S. (2008). Out-of-school and "at risk"? Socio-demographic characteristics, AIDS knowledge and risk perception among young people in northern Tanzania. International Journal of Educational Development, 28(4), 393-404.

Bastien, S. (2009). Access, agency and ambiguity: communication about AIDS among young people in northern Tanzania. Culture, Health and Sexuality, 11(8), 751-65.

Bogale, G.W., Boer, H., Seydel, E.R. (2010). Condom-use among low-literate, rural females in Ethiopia: the role of vulnerability to HIV infection, condom attitude and self efficacy. AIDS Care, 22(7), 851857.

Burke, K., Beegle, K. (2004). Why children aren't attending school: the case of rural Tanzania. Journal of African Economies, 13(2), 333-355.

Chapman, R., White, R.G., Shafer, L.A., Pettifor, A., Mugurungi, O., Ross, D., Pascoe, S., Cowan, F.M., Grosskurt, H., Buve, A., Hayes R.J. (2010). Do behavioral differences help to explain variations in HIV prevalence in adolescents in sub-Saharan Africa? Tropical Medicine and International Health, 15(5), 554-566.

Clark, S., Bruce, J., Dude, A. (2006). Protecting young women from HIV/AIDS: the case against child and adolescent marriage. International Family Planning Perspectives, 32(2), 79-88.

Clark, S., Kabiru, C., Mathur, R. (2010). Relationship transitions among youth in urban Kenya. Journal of Marriage and the Family, 72(1), 73-88.

Dixon-Mueller, R. (2009). Starting young: sexual initiation and HIV prevention in early adolescence. AIDS and Behavior, 13(1), 100-109.

Francis, D., Rimmensberger, N. (2008). Between the cracks : out-of-school youth and discourses of HIV / AIDS. South African Journal of Psychology, 38 (4): 603-613.

Gillespie, S., Greener, R., Whiteside, A., Whitworth, J. (2007). Investigating the empirical evidence for understanding vulnerability and the associations between poverty, HIV infection and AIDS impact. AIDS 21: S1-S5.

Gupta, N., Mahy, M. (2003). Sexual initiation among adolescent girls and boys: trends and differentials in sub-Saharan Africa. Archives of Sexual Behavior, 32(1), 41-53.

Hargreaves, J. R., Bonell, C. P., Boler, T., Boccia, D., Birdthistle, I., Fletcher, A., Pronyk, P. M., Glynn, J. R. (2008a). Systematic review exploring time trends in the association between educational attainment and risk of HIV infection in sub-Saharan Africa. AIDS 22 (3): 403-414.

Hargreaves, J.R., Morison, L.A., Kim, J.C., Bonell, C.P., Porter J.D.H., Watts, C., Busza, J., Phetla, G., Pronyk, P.M. (2008b). The association between school attendance, HIV infection and sexual behavior among young people in rural South Africa. Journal of Epidemiology and Community Health, 62(2), 113-119.

Harrison, A., Cleland, J., Frohlich, J. (2008). Young people's sexual partnerships in KwaZulu-Natal, South Africa: patterns, contextual influences and HIV risk. Studies in Family Planning, 39(4), 295308. 
Katz, I., and D. Low-Beer. (2008). Why has HIV stabilized in South Africa, yet not declined further? Age and sexual behavior patterns among youth. Sexually Transmitted Diseases, 35(10), 837-842.

Kenyon, C., Dlamini, S., Boulle, A., White, R.G., Badri, M. (2009). A network-level explanation for the differences in HIV prevalence in South Africa's racial groups. African Journal of AIDS Research, 8(3), 243-254.

Longfield, K., Glick, A., Waithaka, M., Berman, J. (2004). Relationships between older men and younger women: implications for STIs/HIV in Kenya. Studies in Family Planning, 35(2), 125-134.

Masatu, M.C., Kazaura, M., Ndeki, S., Mwampambe, R. (2009). Predictors of risky sexual behavior among adolescents in Tanzania. AIDS and Behavior, 13(1), 94-99.

Michelo, C., Sandoy, I., Filkesnes, K. (2006). Steep HIV prevalence declines among young people in selected Zambian communities: population-based observations (1995 - 2003). AIDS 20(7): 10311038.

Ndyanabangi, B., Kipp, W. and H.-J. Diesfeld (2004). Reproductive health behavior among in-school and out-of-school youth in Kabarole District, Uganda. African Journal of Reproductive Health, $8(3), 55-67$.

Nobelius, A.M., Kalina, B., Pool, R., Whitworth, J., Chesters, J., Power, R. (2010a). Delaying sexual debut amongst out-of-school youth in rural southwest Uganda. Culture, Health and Sexuality, 12(6), 663-676.

Nobelius, A.M., Kalina, B., Pool, R., Whitworth, J., Chesters, J., Power, R. (2010b). You still need to give her a token of appreciation: the meaning of the exchange of money in the sexual relationships of out-of-school adolescents in rural southwest Uganda. Journal of Sex Research, 13, 1-14.

Shisana, O., Rehle, T., Simbayi, L.C., Zuma, K., Jooste, S., Pillay-van-Wyk, V., Mbelle, N., Van Zyl, J., Parker, W., Zungu, N.P., Pezi, S., the SABSSM III Implementation Team (2009). South African national HIV prevalence, incidence, behaviour and communication survey 2008: A turning tide among teenagers? Cape Town: HSRC Press.

Slonim-Nevo, V., Mukuka, L. (2005). AIDS-related knowledge, attitudes and behavior among adolescents in Zambia. AIDS and Behavior, 9(2), 223-231.

Taffa, N., Bjune, G., Sundby, J., Gaustad, P., Alestrom, A. (2002a). Prevalence of gonococcal and chlamydial infections and sexual risk behavior among youth in Addis Ababa, Ethiopia. Sexually Transmitted Diseases, 29(12), 828-833.

Taffa, N., Klepp, K., Sundby, J., Bjune, G. (2002b). Psychosocial determinants of sexual activity and condom use intention among youth in Addis Ababa, Ethiopia. Int J STD AIDS, 13, 714-719.

Taffa, N., Sundby, J., Bjune, G. (2003). Reproductive health perceptions, beliefs and sexual risk-taking among youth in Addis Ababa, Ethiopia. Patient Education and Counseling, 49(2), 165-169.

UNAIDS (2010). Global report. Geneva, UNAIDS.

UNESCO (2009). Overcoming inequality: Why governance matters. Paris, EFA Global Monitoring Report.

UNFPA (2011, in press). Background paper HIV and out-of-school youth. New York, UNFPA.

Zambuko, O., Mturi, A.J. (2005). Sexual risk behavior among the youth in the era of HIV/AIDS in South Africa. Journal of Biosocial Science, 37(5), 569-84. 
Figure 1: Percentages of primary-school-aged children out-of-school: East Africa (UNESCO - UIS online database 2010)

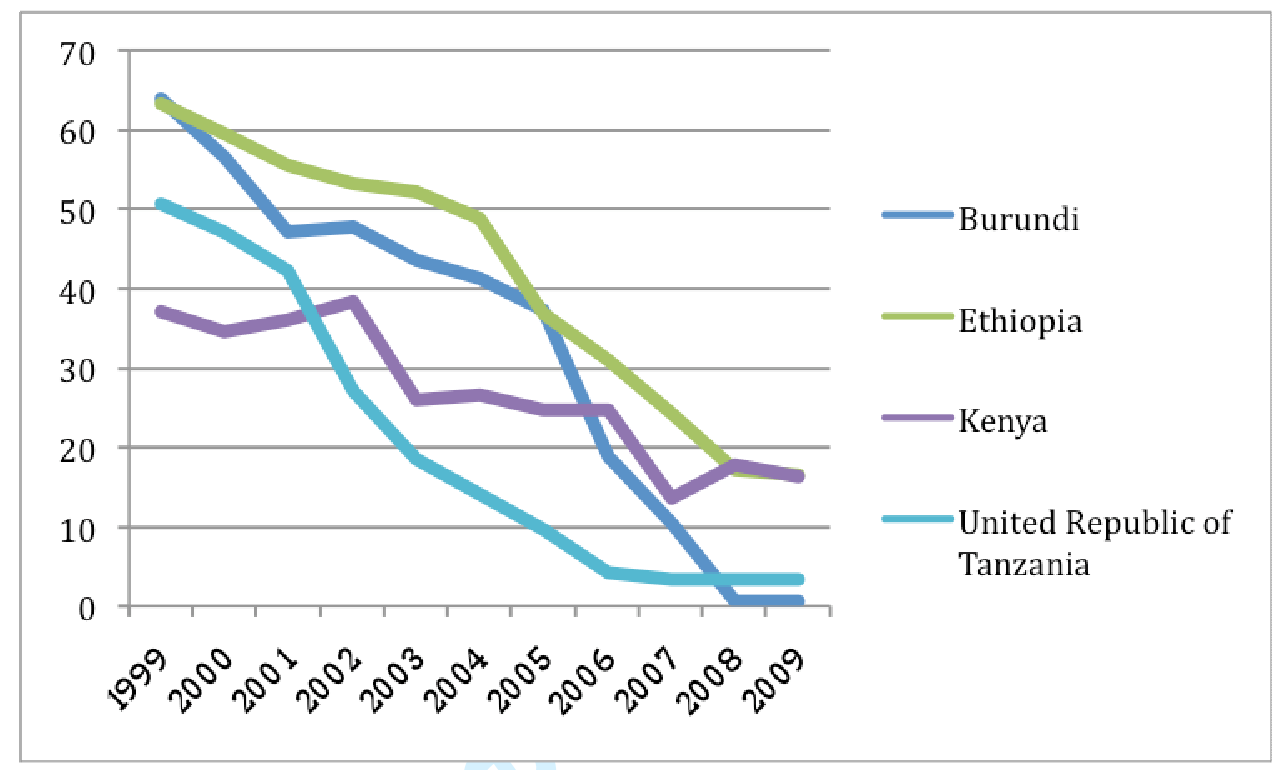


Figure 2: Percentages of primary-school-aged children out-of-school: Southern Africa (UNESCO - UIS online database 2010)

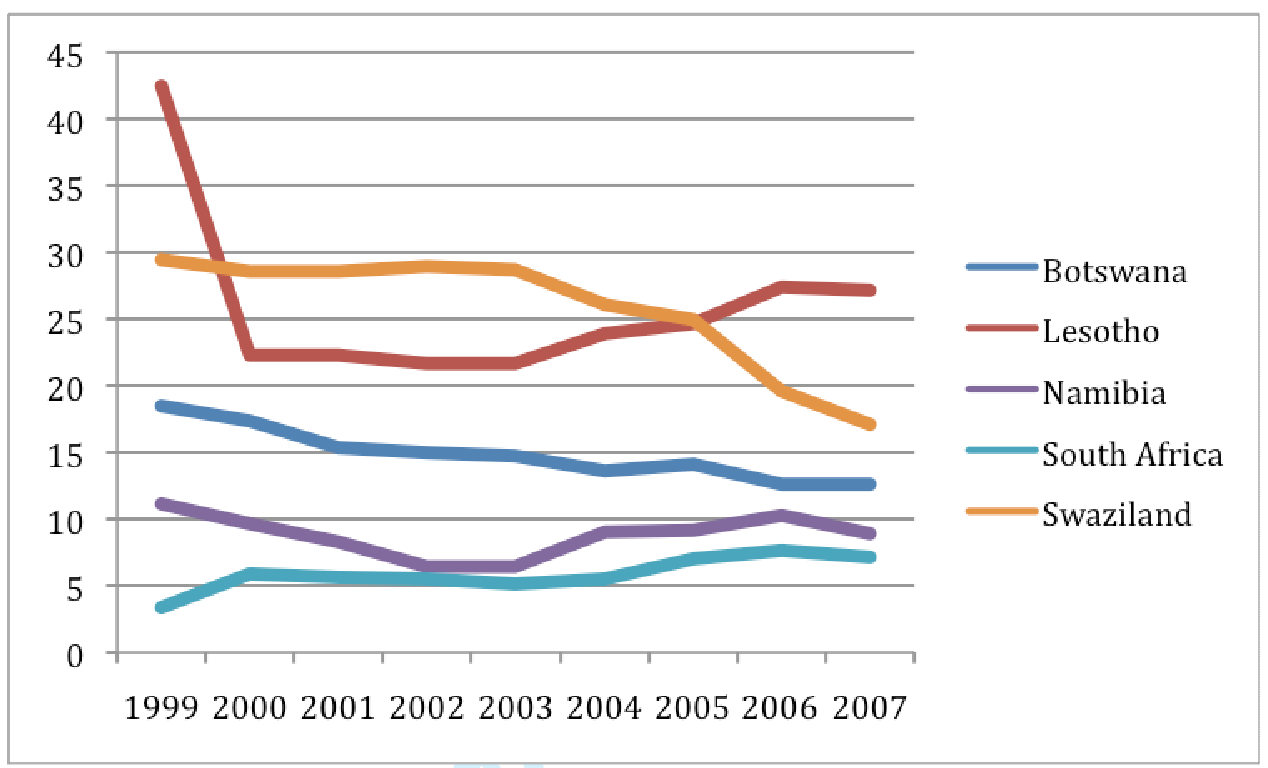


Figure 3: Flow diagram of studies selected for systematic review

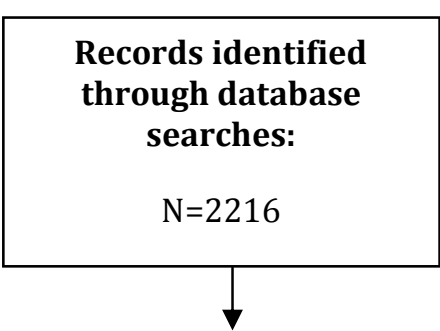

ปั้

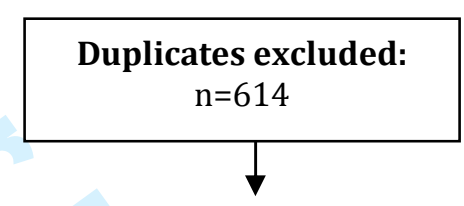

Potentially relevant unique titles screened: $n=1602$

\section{Excluded:}

- not in Eastern of Southern Africa: 300

- not among out-of-school youth: 540

- $\quad$ not reporting in HIV/SRH status or on HIV prevention/SRH promotion: 322

Excluded: 180

Records identified through a targeted search of other sources:

Google Scholar=1, the screening of reference lists $=1$, and websites of international organizations (grey

literature $)=31$

Records identified through key authors: $n=2$

웜 inclusion criteria: $\mathrm{n}=104$

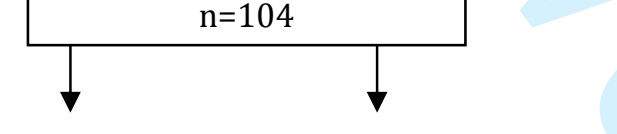

Intervention

Descriptive studies $=48$

key articles $=19$

key articles $=26$ 
Table 1: Overview of key descriptive literature: Cross-sectional studies

\begin{tabular}{|c|c|c|c|c|c|c|c|c|}
\hline $\begin{array}{l}\text { Country } \\
\text { Year }\end{array}$ & First author & $\begin{array}{l}\text { Study } \\
\text { population }\end{array}$ & $\begin{array}{l}\text { Age } \\
\text { group }\end{array}$ & $\begin{array}{l}\text { Sample } \\
\text { size }\end{array}$ & Main themes & Other themes & Main factors & Other factors \\
\hline $\begin{array}{l}\text { Ethiopia } \\
2009\end{array}$ & Erulkar, A & $\begin{array}{l}\text { Out-of- } \\
\text { school urban } \\
\text { females }\end{array}$ & $10-19$ & 1,837 & Sex coercion & $\begin{array}{l}\text { Unwanted } \\
\text { pregnancy }\end{array}$ & $\begin{array}{l}\text { School } \\
\text { attainment }\end{array}$ & $\begin{array}{l}\text { Migrant domestic } \\
\text { worker }\end{array}$ \\
\hline 2007 & Alemu, $\mathrm{H}$ & $\begin{array}{l}\text { Out-of- } \\
\text { school youth } \\
\text { in Bahir town }\end{array}$ & $15-24$ & $\begin{array}{l}628+ \\
q: 46 \text { FGD } \\
10 \text { IDI }\end{array}$ & $\begin{array}{l}\text { Risky sexual } \\
\text { behavior, } \\
\text { condom use }\end{array}$ & & $\begin{array}{l}\text { School } \\
\text { attainment, } \\
\text { being male }\end{array}$ & $\begin{array}{l}\text { Alcohol, khat use, } \\
\text { unemployment }\end{array}$ \\
\hline $\begin{array}{l}2002 \\
(2002, \\
2003)\end{array}$ & Taffa, $\mathrm{N}$ & $\begin{array}{l}\text { In- and out- } \\
\text { of-school } \\
\text { youth in } \\
\text { Addis Ababa }\end{array}$ & $15-24$ & $\begin{array}{l}561 \text { (307 } \\
\text { out-of- } \\
\text { school) }\end{array}$ & $\begin{array}{l}\text { Risky sexual } \\
\text { behavior, } \\
\text { condom use }\end{array}$ & $\begin{array}{l}\text { STI } \\
\text { (chlamydia, } \\
\text { gonorrhoea) }\end{array}$ & $\begin{array}{l}\text { Being out-of- } \\
\text { school, gender }\end{array}$ & Alcohol, khat use \\
\hline 1996 & $\begin{array}{l}\text { Fantahun, } \\
\text { M }\end{array}$ & $\begin{array}{l}\text { Out-of- } \\
\text { school youth }\end{array}$ & - & 1,115 & $\begin{array}{l}\text { HIV/AIDS } \\
\text { knowledge, } \\
\text { practice, } \\
\text { attitude }\end{array}$ & & $\begin{array}{l}\text { Age, sex, } \\
\text { marital status }\end{array}$ & $\begin{array}{l}\text { Education level, } \\
\text { employment }\end{array}$ \\
\hline $\begin{array}{l}\text { South } \\
\text { Africa } \\
2008\end{array}$ & $\begin{array}{l}\text { Hargreaves, } \\
\text { JR }\end{array}$ & Rural youth & $14-25$ & 1,919 & HIV serostatus & $\begin{array}{l}\text { Risky sexual } \\
\text { behavior, } \\
\text { condom use }\end{array}$ & $\begin{array}{l}\text { Being out-of- } \\
\text { school } \\
\text { (secondary sch) }\end{array}$ & \\
\hline 2005 & Zambuko, O & $\begin{array}{l}\text { In- and out- } \\
\text { of-school } \\
\text { youth }\end{array}$ & $14-22$ & 3,126 & Condom use & & $\begin{array}{l}\text { Being out-of- } \\
\text { school, gender }\end{array}$ & Education level \\
\hline $\begin{array}{l}\text { Tanzania } \\
2009\end{array}$ & Bastien, S & $\begin{array}{l}\text { In- and out- } \\
\text { of-school } \\
\text { youth }\end{array}$ & $13-18$ & 1,007 & $\begin{array}{l}\text { HIV/AIDS } \\
\text { knowledge }\end{array}$ & $\begin{array}{l}\text { Credible } \\
\text { source of } \\
\text { information }\end{array}$ & $\begin{array}{l}\text { Urban/rural, } \\
\text { sex }\end{array}$ & $\begin{array}{l}\text { Educational } \\
\text { attainment, socio- } \\
\text { economic }\end{array}$ \\
\hline 2009 & Masatu, M & $\begin{array}{l}\text { Rural in- and } \\
\text { out-of-school } \\
\text { youth }\end{array}$ & $10-19$ & $\begin{array}{l}3,495 \\
(1000 \\
\text { out-of- } \\
\text { school) }\end{array}$ & $\begin{array}{l}\text { Risky sexual } \\
\text { behavior, } \\
\text { condom use }\end{array}$ & & $\begin{array}{l}\text { Age, gender, } \\
\text { marital status, } \\
\text { education, } \\
\text { religion }\end{array}$ & \\
\hline 2008 & Bastien, S & $\begin{array}{l}\text { Urban and } \\
\text { rural out-of- } \\
\text { school youth }\end{array}$ & $13-18$ & 1,007 & $\begin{array}{l}\text { HIV/AIDS } \\
\text { knowledge, risk } \\
\text { perception }\end{array}$ & & $\begin{array}{l}\text { Socio-economic } \\
\text { status, } \\
\text { employment, } \\
\text { age }\end{array}$ & $\begin{array}{l}\text { Religion, tribe, } \\
\text { school } \\
\text { experience/ } \\
\text { culture }\end{array}$ \\
\hline $\begin{array}{l}\text { Uganda } \\
2004\end{array}$ & $\begin{array}{l}\text { Ndyana } \\
\text { bangi, B }\end{array}$ & $\begin{array}{l}\text { In- and out- } \\
\text { of-school } \\
\text { youth }\end{array}$ & $12-21$ & $\begin{array}{l}556(256 \\
\text { out-of- } \\
\text { school) }\end{array}$ & $\begin{array}{l}\text { Risky sexual } \\
\text { behavior, } \\
\text { condom use }\end{array}$ & $\begin{array}{l}\text { HIV/AIDS } \\
\text { knowledge }\end{array}$ & $\begin{array}{l}\text { Being out-of- } \\
\text { school }\end{array}$ & \\
\hline $\begin{array}{l}\text { Zambia } \\
2005 \\
(2007)\end{array}$ & $\begin{array}{l}\text { Slonim-Nevo, } \\
\mathrm{V}\end{array}$ & $\begin{array}{l}\text { Urban/ rural } \\
\text { in- and out- } \\
\text { of-school } \\
\text { youth }\end{array}$ & $10-19$ & $\begin{array}{l}3,360 \\
(1,200 \\
\text { out-of- } \\
\text { school) }\end{array}$ & Child abuse & & $\begin{array}{l}\text { Age, gender, } \\
\text { school } \\
\text { attendance, } \\
\text { marital status, } \\
\text { urban/rural }\end{array}$ & $\begin{array}{l}\text { Parents' } \\
\text { education, family } \\
\text { status, religion }\end{array}$ \\
\hline $\begin{array}{l}\text { Kenya } \\
2008\end{array}$ & Khasakhala, A & $\begin{array}{l}\text { Unmarried } \\
\text { and } \\
\text { unemployed } \\
\text { out-of-school } \\
\text { youth }\end{array}$ & $15-24$ & 3,961 & $\begin{array}{l}\text { Risky sexual } \\
\text { behavior }\end{array}$ & & $\begin{array}{l}\text { Age, age at } \\
\text { sexual debut, } \\
\text { ever pregnant/ } \\
\text { fathered, } \\
\text { alcohol use }\end{array}$ & $\begin{array}{l}\text { Education level, } \\
\text { circumcision } \\
\text { status, } \\
\text { urban/rural } \\
\text { residence }\end{array}$ \\
\hline
\end{tabular}


Table 2: Overview of descriptive literature: Qualitative studies

\begin{tabular}{|c|c|c|c|c|c|c|c|c|}
\hline $\begin{array}{l}\text { Country } \\
\text { Year }\end{array}$ & First author & $\begin{array}{l}\text { Study } \\
\text { population }\end{array}$ & $\begin{array}{l}\text { Age } \\
\text { group }\end{array}$ & $\begin{array}{l}\text { Sample } \\
\text { size }\end{array}$ & Main themes & Other themes & Main factors & Other factors \\
\hline $\begin{array}{l}\text { Uganda } \\
2010 a\end{array}$ & $\begin{array}{l}\text { Nobelius, } \\
\text { AM }\end{array}$ & $\begin{array}{l}\text { Rural out-of- } \\
\text { school youth }\end{array}$ & $13-19$ & $\begin{array}{l}31 \\
\text { (q: FGD) }\end{array}$ & $\begin{array}{l}\text { Risky sexual } \\
\text { behavior } \\
\text { (sexual debut) }\end{array}$ & & $\begin{array}{l}\text { Culture (peer } \\
\text { pressure), } \\
\text { gender }\end{array}$ & $\begin{array}{l}\text { Parental } \\
\text { assistance }\end{array}$ \\
\hline 2010b & $\begin{array}{l}\text { Nobelius, } \\
\text { AM }\end{array}$ & $\begin{array}{l}\text { Rural out-of- } \\
\text { school youth }\end{array}$ & $13-19$ & $\begin{array}{l}31 \\
\text { (q:FGD) }\end{array}$ & $\begin{array}{l}\text { Transactional } \\
\text { sex }\end{array}$ & & Culture, gender & \\
\hline $\begin{array}{l}\text { Tanzania } \\
2009\end{array}$ & Bastien, $\mathrm{S}$ & $\begin{array}{l}\text { In- and out- } \\
\text { of-school } \\
\text { youth in } \\
\text { Kilimanjaro }\end{array}$ & $13-18$ & $\begin{array}{l}78 \\
\text { (q: IDI) }\end{array}$ & $\begin{array}{l}\text { HIV/AIDS } \\
\text { knowledge } \\
\text { (health literacy) }\end{array}$ & & $\begin{array}{l}\text { Being out-of- } \\
\text { school }\end{array}$ & $\begin{array}{l}\text { Culture (social } \\
\text { network) }\end{array}$ \\
\hline $\begin{array}{l}\text { South } \\
\text { Africa } \\
2008\end{array}$ & Francis, D & $\begin{array}{l}\text { Out-of- } \\
\text { school youth }\end{array}$ & $10-18$ & $\begin{array}{l}32 \\
\text { (q: IDI) }\end{array}$ & $\begin{array}{l}\text { Risky sexual } \\
\text { behavior, } \\
\text { condom use }\end{array}$ & & $\begin{array}{l}\text { Culture } \\
\text { (tradition and } \\
\text { peer), gender } \\
\text { relations }\end{array}$ & $\begin{array}{l}\text { Socio-economic } \\
\text { (poverty), } \\
\text { education level, } \\
\text { sense of agency }\end{array}$ \\
\hline
\end{tabular}




\section{Table 3: Significant associations for out-of-school youth}

- $\quad$ More STI infections among out-of-school youth in urban Ethiopia (Taffa 2002); more HIV infection among non-students in rural South Africa (Hargreaves 2008).

- $\quad$ Less HIV knowledge among out-of-school youth both in Tanzania (Bastien 2008, Bastien 2009) and in Uganda (Ndyanabangi 2004)

- $\quad$ Less condom use among out-of-school young women in South Africa, both rural (Hargreaves 2008) and urban (Zambuko 2005). Less condom use among out-of-school young men and women in Uganda (Ndyanabangi 2004) and in urban Ethiopia (Alemu 2007, Taffa 2003).

- $\quad$ More risky sexual behavior among out-of-school youth in Uganda (Ndyanabangi 2004, Nobelius 2010a), in urban Kenya (Khasakhala 2008), in Ethiopia, especially by women (Erulkar 2009) and in South Africa, especially by men (Zambuko 2005)

- $\quad$ Earlier sexual debut among out-of-school youth in Uganda (Ndyanabangi 2004, Nobelius 2010a)

- $\quad$ More sexual activity among out-of-school youth in Uganda (Ndyanabangi 2004), among out-of-school girls in urban Ethiopia (Taffa 2002) and out-of-school boys in rural South Africa (Hargreaves 2008)

- $\quad$ More concurrent or multiple partners among out-of-school young women in urban Ethiopia (Taffa 2003) and for both sexes in rural South Africa (Hargreaves 2008), but less concurrency or multiple partners for out-ofschool boys in Tanzania (Masatu 2009).

- $\quad$ More age mixing among out-of-school girls in rural South Africa (Hargreaves 2008)

- $\quad$ More transactional sex among out-of-school men in urban Ethiopia (Alemu 2007)

- More sexual abuse experienced by out-of-school young women both in urban Ethiopia (Erulkar 2009) and in Zambia (Slonim-Nevo 2005). 